\title{
Arboreal/Arbustive Component Associated to Livestock Systems in San Vicente del Caguán Municipality, Caquetá-Colombia
}

\author{
Ricardo Alberto Martínez Tovar*, Laura Constanza Rojas Basto, Pablo Andrés Motta Delgado, \\ Wilmer Herrera Valencia
}

Misión Verde Amazonía Corporation, Florencia, Colombia

Email: *ramartineztov@gmail.com

How to cite this paper: Tovar, R.A.M., Basto, L.C.R., Delgado, P.A.M. and Valencia, W.H. (2017) Arboreal/Arbustive Component Associated to Livestock Systems in San Vicente del Caguán Municipality, Caquetá-Colombia. American Journal of Plant Sciences, 8, 3162-3173.

https://doi.org/10.4236/ajps.2017.812213

Received: October 19, 2017

Accepted: November 24, 2017

Published: November 27, 2017

Copyright $\odot 2017$ by authors and Scientific Research Publishing Inc. This work is licensed under the Creative Commons Attribution-NonCommercial International License (CC BY-NC 4.0). http://creativecommons.org/licenses/by-nc/4.0/

\begin{abstract}
Livestock is the most important economic activity in San Vicente del Caguán municipality, Caquetá department (located in Colombian Amazon region). Indeed, livestock activities have a big responsibility of Colombian Amazon forest deforestation for extensive grazing lands formation, causing soil degradation processes. However, recently some cattle ranchers have changed their thoughts to a sustainable production, applying different ecological strategies. So, application of silvopastoral systems, which is a very important mode of agroforestry, consists that in the same area and time, it can interact in the ecosystem stratums different species among grasses, shrubs, and trees. On this way, the objective of this study is to determine descriptively the arboreal/arbustive component associated to livestock systems, represented according to its uses in San Vicente del Caguán, Colombia. It was made through a direct survey to 13 smallholders in this municipality. As a result, mainly, we found 58 plant species (49 arboreal and nine arbustive, corresponding to $84.48 \%$ and $15.52 \%$, respectively). Of these, 20 species had more than one use at a time. In fact, the shade was the use most common with 29 species, corresponding to $34.94 \%$ of total species (25 arboreal and just four arbustive, corresponding to $30.12 \%$ and $4.82 \%$, respectively). On this way, according to smallholders surveyed, we can conclude that shade provided by trees integration in silvopastoral systems is for diminishing heat stress on cattle caused by enduring climate change of tropical, thus contributing to good welfare for animals.
\end{abstract}

\section{Keywords}

Amazonia, Agroforestry, Deforestation, Shade Trees, Silvopastoral Systems 


\section{Introduction}

The bovine livestock is an important economic activity in Colombia, especially in Caquetá department/state, which is the $5^{\text {th }}$ position like the department in the greatest number of animals (1,486,685 bovines). Also according to bovine population census done by the Instituto Colombiano Agropecuario-ICA in 2017 [1], San Vicente del Caguán is the municipality of Caquetá department with most animals $(688,004$ bovines), contributing with $46.28 \%$ of the total from that department and $2.93 \%$ of the national total.

Indeed, the San Vicente del Caguán municipality is supported economically by livestock activity, where dual-purpose livestock system is the most common, but this still is too traditional by the extensive way [2]. In fact, this livestock practice has damaged natural ecosystem by irrational deforestation, transforming a big part of the Amazonian forest to large pastures [3] [4]. In addition, soil resource has become less productive [3] [5], to point being a livestock system unsustainable on long [5].

However, recently cattle ranchers have changed their thoughts to a sustainable production, applying different ecological strategies [6] [7]. On this way, application of silvopastoral systems, which are very important modes of agroforestry practice, consists that in the same area and time, it can interact in the ecosystem stratums different species among grasses, shrubs and trees [8] [9].

On the other hand, in livestock production, silvopastoral component/system is a recent trend in agroforestry that in practice, is a low-cost alternative for food production as well as environment protection [10] [11]. Besides, it can promote soil conservation and nutrients recycling while producing fruits, fodder, timber and fuelwood [12] [13], constituting in productivity, environment and socioeconomics benefices [14].

On this way, the aim of this study is to determine descriptively the arboreal/arbustive component associated to livestock systems, represented according to its uses by 13 smallholders in San Vicente del Caguán, Colombia.

\section{Materials and Methods}

Information was taken from a direct survey to 13 livestock smallholders by field professionals in San Vicente del Caguán municipality, Caquetá department (Figure 1). It is located the Southern Colombia at $2^{\circ} 6^{\prime} 55^{\prime \prime} \mathrm{N}, 74^{\circ} 46^{\prime} 12^{\prime \prime} \mathrm{W}$, with an area of $28,300 \mathrm{~km}^{2}$. It has an average elevation of $280 \mathrm{~m}$ and its annual rainfall median is $2486 \mathrm{~mm} /$ year, its mean temperature is $25^{\circ} \mathrm{C}$ and relative humidity is $82 \%$. Indeed, according to the Holdridge life zones, it is classified as wet forest.

On this way, we asked them about trees and shrubs associated to pasture into their farms, respectively. In fact, each one said us about such plants in its common names, moreover, about its respective uses, including: shade, timber, fodder, firewood, medicinal, water conservation and human food.

Then, for guaranteeing the accuracy of field information, each common name of such plants (tree/shrub) was collated and identified using three handbooks for 


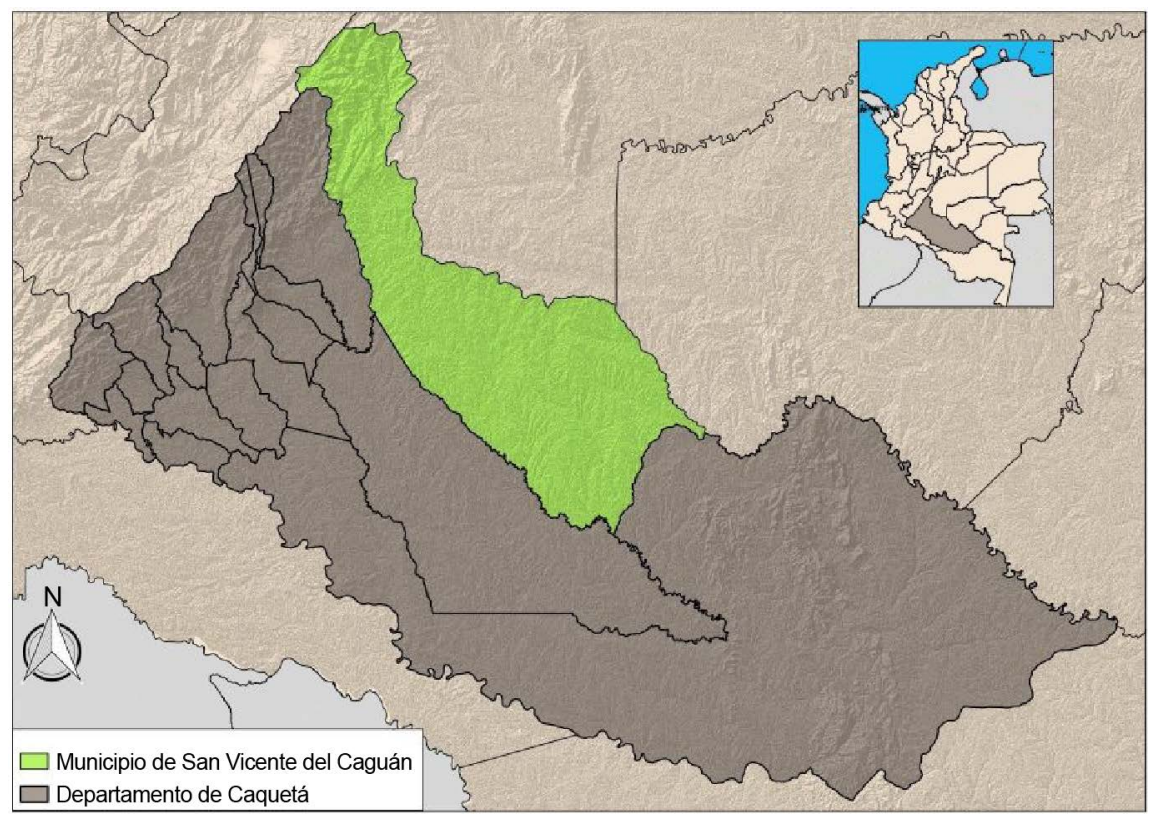

Figure 1. Location of studied livestock farms in San Vicente del Caguán municipality.

plant identification in Colombian Amazon edited by the Instituto Amazónico de Investigaciones Científicas SINCHI [15] [16] [17]. Thus, we determined its respective scientific name. Moreover, according to growth type characteristic of each plant (trees and shrubs), we confirmed the two types in this analysis: 1) arboreal and 2) arbustive, respectively. On the other hand, descriptive statistical was used for data analysis.

\section{Results}

We found 58 plant species (49 arboreal and nine arbustive). Of these species, 20 had more than one use at a time (Table 1). So, arboreal species constitute the largest component of all uses (Figure 2), especially for advantage its shade by livestock producers in San Vicente del Caguán municipality. Indeed, the shade was the use most common with 29 species (25 arboreal and just four arbustive). In contrast, we found no arbustive species used for timber.

Moreover, arbustive species constitute the largest component of all uses, (Figure 2), especially for advantage its shade by livestock producers in San Vicente del Caguán municipality. In fact, we found no arbustive species used for timber.

On this sense, of all found 58 plant species, the proportions of arboreal and arbustive type species correspond to $84.48 \%$ and $15.52 \%$, respectively (Figure 3 ). According to all plant found, arboreal species were the most used in all usages surveyed. So, the shade was the most prominent with $34.94 \%$ of total specie (with a participation of $30.12 \%$ and $4.82 \%$, arboreal and arbustive species, respectively). Although for timber use we did not found arbustive species, all were arboreal species with $21.69 \%$.

In addition, fodder using is the third most important with $14.46 \%$ of the total 
Table 1. Uses of arboreal/arbustive species found in San Vicente del Caguán livestock farms.

\begin{tabular}{|c|c|c|c|c|c|c|c|c|}
\hline \multicolumn{2}{|r|}{ Name } & \multirow{2}{*}{ Type } & \multirow{2}{*}{ Use } & \multirow[b]{2}{*}{ I } & \multicolumn{2}{|r|}{ Name } & \multirow{2}{*}{ Type } & \multirow{2}{*}{ Use } \\
\hline Common & Scientific & & & & Common & Scientific & & \\
\hline Abarco & Cariniana pyriformis & A & $\mathrm{T}$ & | & Guamocerindo & Inga leptocarpa & B & S, W \\
\hline Acacia & Acacia mangium & A & S & | & Guarango & Parkia multijuga & A & $\mathrm{T}$ \\
\hline Aceituno & Vitex cymosa & A & $\mathrm{T}$ & | & Guayabo & Psidium guajava & A & $\mathrm{S}, \mathrm{W}, \mathrm{M}, \mathrm{H}$ \\
\hline Ahumado & Minquartia guianensis & A & $\mathrm{T}$ & | & Guayabomontuno & Terminalia oblonga & A & $\mathrm{T}$ \\
\hline Ahumadochipo & Sterculia amazonica & A & S & | & Higuerón & Ficus insipida & A & $\mathrm{C}$ \\
\hline Anón & Annona squamosa & A & $\mathrm{S}, \mathrm{W}, \mathrm{H}$ & | & Hobo & Spondias mombin & A & $\mathrm{T}$ \\
\hline Árbol del pan & Artocarpus altilis & A & S, F & | & Lacre & Vismia affinis & B & S \\
\hline Balso & Ochroma pyramidale & A & F, C & 1 & Laurel & Ocotea sp. & A & $\mathrm{T}$ \\
\hline Borojó & Borojoa patinoi & B & $\mathrm{F}$ & | & Limón & Citrus limon & B & $\mathrm{S}, \mathrm{H}$ \\
\hline Botón de oro & Tithonia diversifolia & B & $\mathrm{F}$ & | & Mamoncillo & Melicoccus bijugatus & A & S \\
\hline Cachingo & Erythrina fusca & A & S & 1 & Mango & Mangifera indica & A & $S, M$ \\
\hline Caimoyare & Chrysophyllum cainito & A & $\mathrm{W}, \mathrm{M}$ & 1 & Marañón & Anacardium occidentale & A & M \\
\hline Cañofistol & Cassia fistula & A & S & | & Mata raton & Gliricidia sepium & A & S, F, M \\
\hline Carbón & Calliandra riparia & B & $\mathrm{C}$ & I & Melina & Gmelina arborea & A & S, F \\
\hline Carrecillo & Pachira quinata & A & $\mathrm{T}$ & | & Nacedero & Trichanthera gigantea & A & $\mathrm{F}$ \\
\hline Cedro & Cedrela odorata & A & $\mathrm{T}$ & 1 & Naranjo & Citrus sinensis & A & S \\
\hline Ceiba & Ceiba pentandra & A & S & | & Nogal & Cordia alliodora & A & $S, T$ \\
\hline Chicalá & Handroanthus serratifolius & A & $\mathrm{T}$ & | & Palma real & Roystonea regia & A & S \\
\hline Chocho / Choco & Ormosia amazonica & A & S & | & Palo de Cruz & Brownea ariza & A & $S, M$ \\
\hline Cobre & Andira inermis & A & S & | & Pate de vaca & Bauhinia grandiflora & A & S \\
\hline Copal & Hymenaea parvifolia & A & $\mathrm{T}$ & | & Samán & Samanea saman & A & $\mathrm{S}$ \\
\hline Cordoncillo & Pipersp. & B & $\mathrm{F}$ & | & Sangretoro & Virola elongata & A & $S, T$ \\
\hline Costillo & Aspidosperma polyneuron & A & $\mathrm{T}, \mathrm{W}$ & I & Tachuelo & Fagara rhoifolia & A & S \\
\hline Dinde & Maclura tinctoria & A & $\mathrm{T}$ & 1 & Teca & Tectona grandis & A & $S, T$ \\
\hline Dormilón / orejero & Enterolobium cyclocarpum & B & S & 1 & Totumo & Crescentia cujete & A & $\mathrm{F}, \mathrm{W}$ \\
\hline Flormorado & Tabebuia rosea & A & $\mathrm{T}, \mathrm{M}$ & | & Maraco & Couroupita guianensis & A & S \\
\hline Gólgota & Hibiscus rosa-sinensis & B & $\mathrm{F}, \mathrm{M}$ & 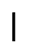 & Balatá & Manilkara bidentata & A & $\mathrm{T}$ \\
\hline Guacharaco & Cupania cinerea & A & $\mathrm{W}$ & I & Yarumo & Cecropia peltata & A & $\mathrm{F}, \mathrm{W}, \mathrm{C}$ \\
\hline Guásimo & Guazuma ulmifolia & A & $\mathrm{F}$ & 1 & Yopo & Anadenanthera peregrina & A & S, W \\
\hline
\end{tabular}

Type: A, arboreal; B, arbustive. Use: S, shade; T, timber; F, fodder; W, firewood; M, medicinal; C, water conservation; $\mathrm{H}$, human food. 


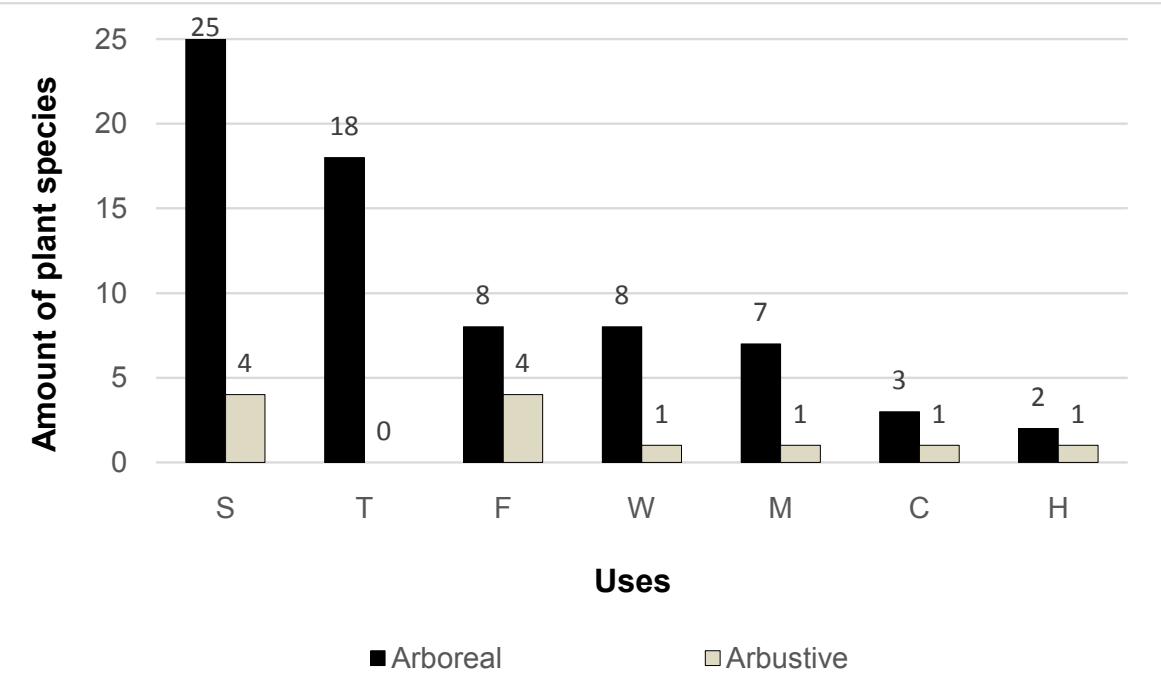

Figure 2. Amount of arboreal/arbustive species used in San Vicente del Caguán livestock farms. Type: ( $\square$ ) arboreal, ( $\square$ ) arbustive. Use: S, shade; $\mathrm{T}$, timber; $\mathrm{F}$, fodder; $\mathrm{W}$, firewood; $\mathrm{M}$, medicinal; $\mathrm{C}$, water conservation; $\mathrm{H}$, human food.

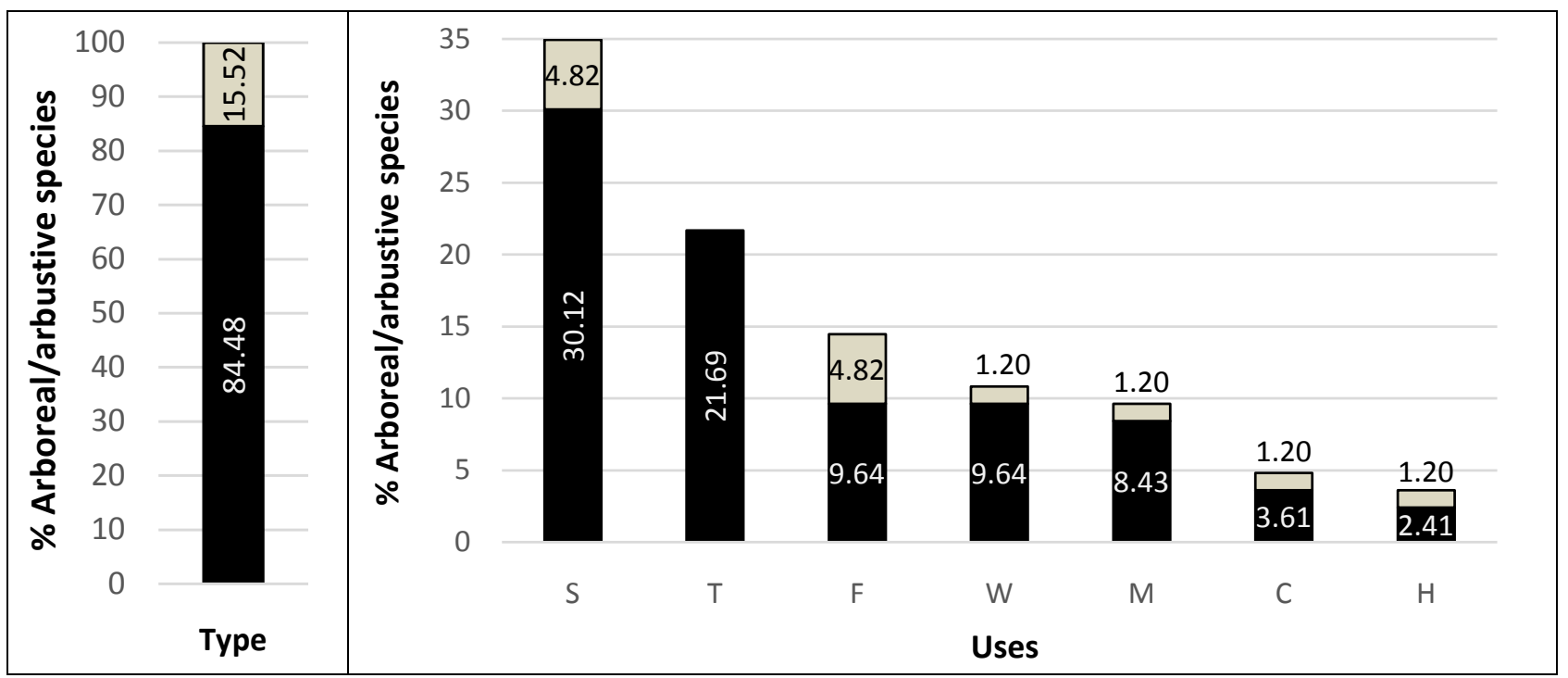

Figure 3. Percent of arboreal/arbustive type species used in San Vicente del Caguán livestock farms. Type: ( $\square$ ) arboreal, ( $\square$ ) arbustive. Use: S, shade; T, timber; F, fodder; W, firewood; M, medicinal; C, water conservation; $\mathrm{H}$, human food.

of the plants found (with a participation of $9.64 \%$ and $4.82 \%$, arboreal and arbustive, respectively.). The rest of uses (firewood, medicinal, water conservation and human food) have a short participation with $10.84 \%, 9.64 \%, 4.82 \%$ and $3.61 \%$, respectively. Indeed, in all these uses, arboreal species were more used than arbustive species, each one of these latter with just $1.20 \%$ of participation of all plant found (Figure 3).

\section{Discussions}

Amazon forest is the greatest rainforest on Earth, which has a notable influence on global climate, regulating global water and carbon cycles [18] [19]. However, 
a major of Amazon soils are poor in inorganic nutrients, but naturally, its fertility relays on nutrient cycling from organic matter via litter [20] [21] [22]. So, organic matter is formed and incorporated from fallen leaves decomposition of rainforest trees for fertility maintaining [22].

There is the importance of trees for Amazon soil qualities maintaining. Nevertheless, deforestation has been a constant process for livestock expanding in Colombian Amazon region, transforming its rainforests to grazing pastures [23]. Indeed, deforestation has environmental effects to Amazonia [24], especially, resulting in its soil degradation process [23] [25] [26]. Thereby, balance on the soil-plan-animal system is interrupted, causing ecological disturbance [25] [27].

Although Colombian Amazon forest has been affected by deforestation for grazing pasture establishment in livestock activity, this activity is indeed, the most important economic holding in San Vicente del Caguán municipality, where the dual purpose is the most common production system, but still is a too traditional way with extensive grazing [2] [25].

According to our results, we found that arboreal species $(n=49)$ were more numerous than arbustive species $(n=9)$ in all livestock farms visited. In this sense, we had waited that arboreal species were most used for timber, because there are a large number of timber tree species for logging in Colombian Amazon region [28]. But, those were mostly used for shade. Nevertheless, some species have more one use at the same time.

In fact, $P$. guajava was arboreal species with the most uses (four: shade, timber, medicinal and human food) by smallholders surveyed in this study. On one hand, this species is widely used in tropical agro-pastoral and agro-silvopastoral systems for its positive impact in some environments [29]. But otherwise, it is considered an invasive species in other regions, which has high dispersal and seed production that requires control practices of its density [30].

In addition, three arboreal species were found: $A$. squamosa, G. sepium and $C$. peltata, which had three combined uses at the same time but not for timber. Indeed, the two first species are commonly used in different agro-silvopastoral systems, where smallholders use their shade, mainly [31], as well as smallholders surveyed. Moreover, fruit A. squamosal is very used for human food and its timber for firewood [31]. G. sepium is a leguminous plant that is widely used for fodder with high yield production and high nutritional quality [32] [33] [34] [35]. Likewise, its leaves are just used for anti-atherogenic like medicinal [36]. However, this species has a special ability for $\mathrm{N}$ fixation, being used for intercropping and soil proprieties stabilization [31] [37] [38] and as alley cropping in Indonesia [39].

Even smallholder surveyed in this study said Yarumo tree ( $C$. peltata) was used for fodder, firewood and water conservation; this arboreal species was not widely used in silvopastoral systems. In fact, there was a study about the silvopastoral usage of $C$. peltata in Guatemala, resulting in a species with high forage potential [40]. However, this tree has a lot of medicinal uses in Venezuela and 
other tropical regions [41] [42] [43].

On the other hand, dual-purpose cattle production system involves bovine crossbreeding between types Bos taurus (humpless cattle of European and northern Asiatic origin, where is temperate climates and fertile soils) and Bos indicus or Zebu (humped cattle of southern Asiatic origin, where is very warm climates and poorly fertile soils) [44] [45]. So, B. taurus gives high dairy production, in our case dual-purpose system; and $B$. indicus gives rusticity and high adaptability to warm climates, so similar to tropical region [45]. On this, those cattle crossbreeding are made for achieving dual-purpose production system in San Vicente del Caguán municipality [46], as well as other places of tropical America [47] [48] [49].

Nevertheless, cattle adaptive capacities are not successful to endure high solar radiation [50] and climate change of tropical region, causing heat stress on it [51]. Indeed, this stress has acute effects on cattle welfare, therefore on its productivity either [52]. Thus, a way for lessening such effects is shade usage through the integration of trees to pastures in silvopastoral systems [53] [54], contributing to good welfare for animals [54] [55].

On this way, according to smallholders surveyed, we can conclude that shade was the most common use, and it was provided by trees integration for diminishing heat stress on cattle caused by enduring high solar radiation and climate change of tropical, thus contributing to good welfare for animals. However, some authors say pasture shade does not have significant effects on cow improvement productivity in tropics [56]. In addition, shade may decrease the pasture biomass, contributing to soil compaction in the shaded areas due to the increase in the number of animals looking for comfort [57].

On the other hand, the integrated trees to pastures in silvopastoral systems give a lot of other benefits in livestock production [31] [55] [58] [59] [60], especially when managed with a greater trees density [61]. Thus benefit not only includes animal welfare, but that also improves: soil fertility by nutrient dynamics; forage production; carrying capacity of the land; environmental conditions, increasing relative humidity, carbon sequestration/accumulation and reducing greenhouse gas emissions [62]. Thereby, we recommend this system, not only by these benefits mentioned but also for farmer incomes by higher farm outputs, indeed, which is a cleaner way of achieving a biological, ecological and socio-economic livestock production efficiently and sustainably.

\section{Acknowledgements}

This study is a part of result report of the project: "Implementation and validation of alternative methods for cattle production in Caquetá Department" (BPIN: 2013000100164), which is financed by Science Technology and Innovation Founding (FCTeI) from Sistema General de Regalías, Colombia (SGR), executed by the Gobernación de Caquetá, and operated by the Misión Verde Amazonía Corporation, MVA (http://misionverdeamazonia.org/). 


\section{References}

[1] Instituto Colombiano Agropecuario-ICA. (2017) Censo Pecuario Nacional. Censo Bovino en Colombia.

http://https://www.ica.gov.co/Areas/Pecuaria/Servicios/Epidemiologia-Veterinaria/ Censos-2016/Censo-2017.aspx2008.aspx

[2] Alcandía de San Vicente del Caguán-Caquetá. (2016) Información General. http://www.sanvicentedelcaguan-caqueta.gov.co/informacion_general.shtml

[3] Peña-Venegas, C.P. and Cardona, G.I. (2010) Dinámica de los suelos amazónicos: Procesos de degradación y alternativas para su recuperación (No. LC-0596). Instituto Amazónico de Investigaciones Científicas-Sinchi. [Dynamics of Amazonian Soils: Degradation Process and Alternatives for Their Recovery (No.LC-0596).] Ministerio de Ambiente, Vivienda y Desarrollo Territorial, Bogotá, D.C.

[4] Murcia, G.U., Huertas, C.M., Rodríguez, J.M. and Castellanos, H.O. (2011) Monitoreo de los bosques y otras coberturas de la Amazonia Colombiana, a escala 1:100.000. [Monitoring of Forests and Other Coverages of the Colombian Amazon, at a Scale of 1:100,000. Multitemporal Changes in the Period 2002 to 2007.] Cambios multitemporales en el periodo 2002 al 2007. Instituto Amazónico de Investigaciones Científica-Sinchi. Bogotá, D.C.

[5] Siavosh, S., Rivera, J. and Gómez, M. (2000) Impacto de sistemas de ganadería sobre las características físicas, químicas y biológicas de suelos en los Andes de Colombia. [Impact of Livestock Systems on the Physical, Chemical and Biological Characteristics of Soils in the Andes of Colombia.] In conferencia electrónica de la FAO: agroforestería para la producción animal en Latinoamérica.

[6] Durant, D., Tichit, M., Kerneis, E. and Fritz, H. (2008) Management of Agricultural Wet Grasslands for Breeding Waders: Integrating Ecological and Livestock System Perspectives-A Review. Biodiversity and Conservation, 17, 2275-2295. https://doi.org/10.1007/s10531-007-9310-3

[7] Calle, Z., Murgueitio, E., Chará, J., Zuluaga, A.F., Uribe, F., Galindo, A., Solarte, L.H. and Calle, A. (2013) Integrating Sustainable Cattle Ranching, Forestry and Landscape Restoration into Intensive Silvopastoral Systems. In New Frontiers in Tropical Biology: The Next 50 Years (A Joint Meeting of ATBC and OTS).

[8] Swaminathan, M.S. (1987) The Promise of Agroforestry for Ecological and Nutrition Security. In: Steppler, H.A. and Nair, P.R., Eds., Agroforestry: A Decade of Development, International Council for Research in Agroforestry-ICRAF, Nairobi, Kenya, 25-41.

[9] Sanchez, P.A. (1995) Science in Agroforestry. Agroforestry Systems, 30, 5-55. https://doi.org/10.1007/BF00708912

[10] Nair, P.R. (1993) An Introduction to Agroforestry. Kluwer Academic Publishers, The Netherlands. https://doi.org/10.1007/978-94-011-1608-4

[11] Ibrahim, M., Guerra, L., Casasola, F. and Neely, C. (2010) Importance of Silvopastoral Systems for Mitigation of Climate Change and Harnessing of Environmental Benefits. Grassland Carbon Sequestration: Management, Policy and Economics, 11, 189.

[12] Musálem-Santiago, M.Á. (2002) Sistemas agrosilvopastoriles: una alternativa de desarrollo rural sustentable para el trópico mexicano. [Impact of Livestock Systems on the Physical, Chemical and Biological Characteristics of Soils in the Andes of Colombia.] Revista Chapingo Serie Ciencias Forestales y del Ambiente, 8, 91-100.

[13] Montagnini, F. (1992) Sistemas agroforestales: principios y aplicaciones en los 
trópicos (No. 634.99/M764). [Agroforestry Systems: Principles and Application in the Tropics (No. 634.99/M764).] Organización para estudiostropicales.

[14] Murgueitio, E., Xóchitl, F.M., Calle, D.Z., Chará, J.D., Barahona, R., Molina, D.C. and Uribe, T.F. (2015) Productividad en sistemas silvopastoriles intensivos en América Latina. [Productivity in Intensive Silvopastoral Systems in LatinAmerica.] In: Montagnini, F., Somarriba, E., Murgueito, E., Fassola, H. and Eibl, B., Eds., Sistemas agroforestales: funciones productivas, socioeconómicas y ambientales, CIPAV, CATIE, Cali, 59-102.

[15] Camacho, R.L. and López, D.C. (2002) Manual de identificación de especies maderables objeto de comercio en la Amazonia colombiana. [Productivity in Intensive Silvopastoral Systems in Latin America.] Instituto Amazónico de Investigaciones Científicas "SINCHI".

[16] Camacho, R.L. and Montero, M.I. (2005) Manual de identificación de especies forestales con manejo certificable por comunidades. [Identification Handbook of Forest Species with Certifiable Management by Communities.] Instituto Amazónico de Investigaciones Científicas "SINCHI".

[17] López, D.C., Arboleda, N.C. and Toro, J.C. (2011) Plantas introducidas, establecidas e invasoras en Amazonia colombiana. [Introduced, Established and Invasive Plants in Colombian Amazonia.] Instituto Amazónico de Investigaciones Científicas "SINCHI".

[18] Moran, E.F., Brondizio, E., Mausel, P. and Wu, Y. (1994) Integrating Amazonian Vegetation, Land-Use, and Satellite Data. BioScience, 44, 329-338. https://doi.org/10.2307/1312383

[19] Foley, J.A., Asner, G.P., Costa, M.H., Coe, M.T., DeFries, R., Gibbs, H.K., Howard, E.A., Olson, S., Patz, J., Ramankutty, N. and Snyder, P. (2007) Amazonia Revealed: Forest Degradation and Loss of Ecosystem Goods and Services in the Amazon Basin. Frontiers in Ecology and the Environment, 5, 25-32. https://doi.org/10.1890/1540-9295(2007)5[25:ARFDAL]2.0.CO;2

[20] Tiessen, H., Cuevas, E. and Chacon, P. (1994) The Role of Soil Organic Matter in Sustaining Soil Fertility. Nature, 371, 783-785. https://doi.org/10.1038/371783a0

[21] Grau, O., Peñuelas, J., Ferry, B., Freycon, V., Blanc, L., Desprez, M. and Guitet, S. (2017) Nutrient-Cycling Mechanisms Other Than the Direct Absorption from Soil May Control Forest Structure and Dynamics in Poor Amazonian Soils. Scientific Reports, 7, 45017. https://doi.org/10.1038/srep45017

[22] Ge, X., Zeng, L., Xiao, W., Huang, Z., Geng, X. and Tan, B. (2013) Effect of Litter Substrate Quality and Soil Nutrients on Forest Litter Decomposition: A Review. Acta Ecologica Sinica, 33, 102-108. https://doi.org/10.1016/j.chnaes.2013.01.006

[23] Murgueitio, R. (1999) Reconversión ambiental y social de la ganadería bovina en Colombia. [Environmental and Social Reconversion of Bovine Cattle in Colombia.] Fundación CIPAV.

[24] Skole, D.L., Chomentowski, W.H., Salas, W.A. and Nobre, A.D. (1994) Physical and Human Dimensions of Deforestation in Amazonia. BioScience, 44, 314-322. https://doi.org/10.2307/1312381

[25] Sadeghian, S. (2003) Impacto de la ganadería sobre el suelo, alternativas sostenibles de manejo. [Impact of Livestock on Soil, Sustainable Management Alternatives.] In SIMPOSIO Nacional de Ganadería Ecológica.

[26] Food and Agriculture Organization of the United Nations, FAO (2006) Livestock's Long Shadow: Environmental Issues and Options. FAO, Rome. 
[27] Sánchez, S., Hernández, M. and Ruz, F. (2011) Alternativas de manejo de la fertilidad del suelo en ecosistemas agropecuarios. [Alternatives for the Management of Soil Fertility in Agricultural Ecosystems.] Pastos y Forrajes, 34, 375-392.

[28] Caicedo-Llano, N. (2014) A Methodology to Select a Group of Species among 131 Tropical (Colombian) Species for Bowed Timber Applications. Maderas. Ciencia $y$ tecnología, 16, 245-264. https://doi.org/10.4067/S0718-221X2014005000020

[29] Heuzé, V., Tran, G., Bastianelli, D. and Lebas, F. (2015) Guava (Psidiumguajava). Feedipedia, Animal Feed Resources Information System, INRA CIRAD AFZ and FAO. http://agritrop.cirad.fr/582480/7/ID582480_ENG.pdf

[30] Olivares-Pérez, J., Rojas-Hernández, S., Avilés-Nova, F., Camacho-Díaz, L.M., Cipriano-Salazar, M., Jiménez-Guillén, R. and Quiroz-Cardozo, F. (2016) Uses of Non-Leguminous Trees in Silvopastoral Systems in the South of the State of Mexico. Ecosistemas y Recursos Agropecuarios, 3, 193-202.

[31] Soni, M.L., Subbulakshmi, V., Yadava, N.D., Tewari, J.C. and Dagar, J.C. (2016) Silvopastoral Agroforestry Systems: Lifeline for Dry Regions. In: Dagar, J.C. and Tewari, J.C., Eds., Agroforestry Research Developments: Anecdotal to Modern Science. Agroforestry Research Developments, 1. Nova Science Publisher, Inc., New York, 245-305.

[32] Awotoye, O.O., Ogunbanjo, O.R., Jeminiwa, S.M., Okanlawon, F.B. and Oyelami, B.A. (2016) Comparative Evaluation of Fodder Yield and Leaf Quality of Some Selected Tree Species. Environment and Ecology Research, 4, 116-118.

[33] Edvan, R., Carneiro, M., Magalhães, J., Albuquerque, D., Silva, M., Bezerra, L., Oliveira, R. and Santos, E. (2014) The Forage Yield of Gliricidia sepium during the Rainy and Dry Seasons Following Pruning Management in Brazil. Ciencia e Investigación Agraria, 41, 309-316. https://doi.org/10.4067/S0718-16202014000300003

[34] Andrade, B.M., de Souza, S.F., Santos, C.M., dos Santos Medeiros, S., da Mota, P.S. and Curado, F.F. (2015) Uso da gliricídia (Gliricidia sepium) para alimentação animal em Sistemas Agropecuários Sustentáveis. [Use of Gliricidia (Gliricidiasepium) for Animal Feeding in Sustainable Agricultural Systems.] Scientia Plena, 11, 1-7.

[35] Rangel, J.D. and Muniz, E.N. (2011) Implantação e manejo de legumineira com gliricídia (Gliricidia sepium). [Implantation and Management of Legume Tree with Gliricidia (Gliricidiasepium).] EMBRAPA (Circular Técnica 63), 5 p.

[36] Fasola, T.R., Olagunju, B.O. and Robert, A.B. (2014) Correlating Bark Thickness and Girth of Some Medicinal Trees. International Journal of Environment, 3, 287-301. https://doi.org/10.3126/ije.v3i2.10642

[37] Jayasundara, H.P., Dennett, M.D. and Sangakkara, U.R. (1997) Biological Nitrogen Fixation in Gliricidia sepium and Leucaena leucocephala and Transfer of Fixed Nitrogen to an Associated Grass. Tropical Grasslands, 31, 529-537.

[38] Villanueva-López, G., Martínez-Zurimendi, P., Ramírez-Avilés, L., Casanova-Lugo, F. and Jarquín-Sánchez, A. (2014) Influence of Livestock Systems with Live Fences of Gliricidia sepium on Several Soil Properties in Tabasco, Mexico. Ciencia e Investigación Agraria, 41, 175-186. https://doi.org/10.4067/S0718-16202014000200004

[39] Sukanten, I.W., Nitis, I.M., Lana, K., Suama, M. and Uchida, S. (1995) Growth and Fodder Yield of the Gliricidiasepium Provenances in Alley Cropping System in dryland Farming Area in Bali, Indonesia. Asian-Australasian Journal of Animal Sciences, 8, 95-200.

[40] Hernández, S. and Benavides, J. (1995) Potencial forrajero de especies leñosas de los bosques secundarios de El Petén, Guatemala. [Fodder Potential of Woody Species of Secondary Forest in El Petén, Guatemala.] Agroforestería en las Américas, 2, 15-22. 
[41] Figueroa, J., Sanoja, E. and Delgado, L. (2010) Árboles utilizados como productoes forestales no maderables en la cuenca alta del río Botanamo, Estado Bolívar, Venezuela. [Trees Useful as Non Timber Forest Products in the Botanamo Upper River Basin, Bolívar State, Venezuela.] Acta Botánica Venezuelica, 119-135.

[42] Mansanares, K. (2014) Aprovechamiento de servicios ecosistémicos por una comunidad. [Use of Ecosystem Services by a Community.] Revista Cubana de Ciencias Forestales, 2, 45-54.

[43] Neulinger, K., Vogl, C.R. and Alayón-Gamboa, J.A. (2013) Plant Species and Their Uses in Homegardens of Migrant Maya and Mestizo Smallholder Farmers in Calakmul, Campeche, Mexico. Journal of Ethnobiology, 33, 105-124. https://doi.org/10.2993/0278-0771-33.1.105

[44] Phillips, R.W. (1961) World Distribution of the Major Types of Cattle. Journal of Heredity, 52, 207-213. https://doi.org/10.1093/oxfordjournals.jhered.a107071

[45] Turrialba, C.R. (1982) Sistemas de producción bovina de doble propósito para pequeños productores. [Dual Purpose Cattle Production Systems for Small Producers.] In: Ruíz-Flores, A. and de Vaccaro, L.P., Eds., Sistemas de producción con bovinos en el trópico americano, Centro Agronómico Tropical de Investigaciones y Enseñanza Programa Agricultura Tropical Sostenible, Maracay Universidad Central de Venezuela, 137-157.

[46] Martínez-Tovar, R.A., Herrera-Valencia, W. and Motta-Delgado, P.A. (2017) Razas y cruces bovinos de doble propósito en el departamento del Caquetá. [Breeds and Crosses of Dual-Purpose Bovines in the Caquetá Department.] Editorial Misión Verde Amazonía: Corporación para el Desarrollo Sostenible y Mitigación de Cambio Climático. Florencia-Caquetá, Colombia.

[47] Rojo-Rubio, R., Vázquez-Armijo, J.F., Pérez-Hernández, P., Mendoza-Martínez, G.D., Salem, A.Z., Albarrán-Portillo, B., González-Reyna, A., Hernández-Martínez, J., Rebollar-Rebollar, S., Cardozo-Jiménez, D. and Dorantes-Coronado, E.J. (2009) Dual Purpose Cattle Production in Mexico. Tropical Animal Health and Production, 41, 715-721. https://doi.org/10.1007/s11250-008-9249-8

[48] Ojango, J., Urbina, M., Benard, M., Corrales, R., Oyieng, E. and Hoek, R.V. (2016) Increasing the Productivity of Dual-Purpose Cattle in Nicaragua through the Use of Appropriate Breed Types and Application of Best Husbandry Practices. Baseline Report on the Production Systems in Camoapa and Matiguas.

[49] Koger, M. (2015) Livestock Improvement in Tropical America. Revista Ceiba, 9, 41-49.

[50] Tucker, C.B., Rogers, A.R. and Schütz, K.E. (2008) Effect of Solar Radiation on Dairy Cattle Behaviour, Use of Shade and Body Temperature in a Pasture-Based System. Applied Animal Behaviour Science, 109, 141-154. https://doi.org/10.1016/j.applanim.2007.03.015

[51] Sossidou, E.N., Tsiplakou, E. and Zervas, G. (2014) Options for Managing Livestock Production Systems to Adapt to Climate Change. Journal of Earth Science and Engineering, 4.

[52] Kerr, S.R. (2015) Livestock Heat Stress: Recognition, Response, and Prevention. Washington State University Extension Fact Sheet (FS157E).

[53] Lopes, L.B., Eckstein, C., Pina, D.S. and Carnevalli, R.A. (2016) The Influence of Trees on the thermal Environment and Behaviour of Grazing Heifers in Brazilian Midwest. Tropical Animal Health and Production, 48, 755-761. https://doi.org/10.1007/s11250-016-1021-x

[54] Karvatte, N., Klosowski, E.S., de Almeida, R.G., Mesquita, E.E., de Oliveira, C.C. 
and Alves, F.V. (2016) Shading Effect on Microclimate and Thermal Comfort Indexes in Integrated Crop-Livestock-Forest Systems in the Brazilian Midwest. International Journal of Biometeorology, 60, 1933-1941. https://doi.org/10.1007/s00484-016-1180-5

[55] Broom, D.M., Galindo, F.A. and Murgueitio, E. (2013) Sustainable, Efficient Livestock Production with High Biodiversity and Good Welfare for Animals. Proceedings of the Royal Society, 280, 2025. https://doi.org/10.1098/rspb.2013.2025

[56] Ainsworth, J.A., Moe, S.R. and Skarpe, C. (2012) Pasture Shade and Farm Management Effects on Cow Productivity in the Tropics. Agriculture, Ecosystems and Environment, 155, 105-110. https://doi.org/10.1016/j.agee.2012.04.005

[57] Paciullo, D.S., Castro, C.R., Gomide, C.A., Fernandes, P.B., Rocha, W.S., Müller, M.D. and Rossiello, R.O.P. (2010) Soil Bulk Density and Biomass Partitioning of Brachiaria decumbens in a Silvopastoral System. Scientia Agricola, 67, 598-603. https://doi.org/10.1590/S0103-90162010000500014

[58] Peri, P.L., Dube, F. and Varella, A.C. (2016) Silvopastoral Systems in the Subtropical and Temperate Zones of South America: An Overview. In: Peri, P., Dube, F. and Varella, A., Eds., Silvopastoral Systems in Southern South America, Advances in Agroforestry, Vol. 11, Springer, Cham.

https://doi.org/10.1007/978-3-319-24109-8_1

[59] Montagnini, F., Ibrahim, I. and Murgueitio, E. (2013) Silvopastoral Systems and Climate Change Mitigation in Latin America. Bois et Forêts des Tropiques, 316, 3-16.

[60] Nitis, I.M. (1997) Silvipastural Systems in Tropical Context. XVIII International Grassland Congress 2000.

[61] Nahed-Toral, J., Valdivieso-Pérez, A., Aguilar-Jiménez, R., Cámara-Cordova, J. and Grande-Cano, D. (2013) Silvopastoral Systems with Traditional Management in Southeastern Mexico: A Prototype of Livestock Agroforestry for Cleaner Production. Journal of Cleaner Production, 57, 266-279. https://doi.org/10.1016/j.jclepro.2013.06.020

[62] Gaitán, L., Läderach, P., Graefe, S., Rao, I. and van der Hoek, R. (2016) Climate-Smart Livestock Systems: An Assessment of Carbon Stocks and GHG Emissions in Nicaragua. PloS One, 11, e0167949. https://doi.org/10.1371/journal.pone.0167949 